IRA-International Journal of Education \&

Multidisciplinary Studies

ISSN 2455-2526; Vol.15, Issue 01 (April, 2019)

Pg. no. 16-23.

Institute of Research Advances

http://research-advances.org/index.php/IJEMS

\title{
Why Could They Win Out in the Teaching Competition?
}

\section{LU Zhirong}

School of Foreign Studies, Yangtze University, Hubei, 434023 PRC China.

Type of Work: Peer Reviewed

DOl: http://dx.doi.org/10.21013/jems.v15.n1.p2

How to cite this paper:

Zhirong, LU. (2019). Why Could They Win Out in the Teaching Competition?. IRA International Journal of Education and Multidisciplinary Studies (ISSN 2455-2526), 15(1), 16-23. doi: http://dx.doi.org/10.21013/jems.v15.n1.p2

(C) Institute of Research Advances.

This work is licensed under a Creative Commons Attribution-Non Commercial 4.0 International License subject to a proper citation to the publication source of the work.

Disclaimer: The scholarly papers as reviewed and published by the Institute of Research Advances (IRA) are the views and opinions of their respective authors and are not the views or opinions of the IRA. The IRA disclaims of any harm or loss caused due to the published content to any party.

Institute of Research Advances is an institutional publisher member of Publishers International Linking Association Inc. (PILA-CrossRef), USA. The institute is an institutional signatory to the Budapest Open Access Initiative, Hungary advocating the open access of scientific and scholarly knowledge. The Institute is a registered content provider under Open Access Initiative Protocol for Metadata Harvesting (OAI-PMH).

The journal is indexed \& included in WorldCat Discovery Service (USA), CrossRef Metadata Search (USA), WorldCat (USA), OCLC (USA), Open J-Gate (India), EZB (Germany) Scilit (Switzerland), Airiti (China), Bielefeld Academic Search Engine (BASE) of Bielefeld University, Germany, PKP Index of Simon Fraser University, Canada. 


\begin{abstract}
Teaching competition is a very effective means to promote the fast development of teachers in universities and colleges in China, which benefits both teachers and students a lot. This research explores various factors contributing to the success in teaching competition by using the methods of classroom observation, interview and document research. The research uses rich examples to illustrate that personal qualities and theoretical knowledge, personal abilities and collaboration with others can never be underestimated.
\end{abstract}

Key-words: factors; teaching competition; success

\title{
1 Introduction
}

Hubei province China has witnessed 6 province-wide teaching competitions among young teachers from universities and colleges in Hubei, which is held biennially to promote the construction of teaching staff, to stimulate young teachers to update their teaching concept and grasp modern teaching pedagogies.

This competition is vital and influential, which has attracted the attention and participation of 30,000 teachers from 85 province-wide universities and colleges. The contestants are not common young teachers, instead, they are well-chosen. Before they get the opportunities for the province-wide teaching competition, all of them have gone through 4 elimination series with numerous rivals.

The competition is made up of three parts: instructional design, classroom teaching and teaching reflections. In order to embody the competition concept of "teaching a course well", contestants are required to finish and hand in complete teaching design for a course consisting of 20 sections according to the competition rules. On the very day of the competition, the contestant will draw one section at random, and finish the detailed teaching design and PPT needed in a demonstration in the classroom teaching. The most important part is the 20-minute classroom teaching, followed by 5 -minute answering questions raised by 7 distinguished judges.

A lot of contestants realize they have benefited a lot from the completion, especially from the perspective of teaching design, making courseware and bettering flexibility in classroom teaching.

\section{Factors Contributing to their Success in Teaching Competition}

Although every contestant has a strong intention to win out in the teaching competition after about one-year backbreaking preparation, only the most capable and lucky contestants can finally embrace success.

After witnessing the last 3 competitions in 2014, 2016 and 2018 in Wuhan Hubei province and offering the last 3 English contestants advice, I hold the three factors bring about the contestants' success.

\subsection{Personal qualities and theoretical knowledge}

\subsubsection{Personal qualities}

Excellent contestants have the distinctive and good qualities: bearing valuable sentiments of education of loving both teaching and students; being ready to broaden their horizon from different perspectives and explore new knowledge; being enthusiastic in teaching, etc. All of these good qualities could be embodied from their teaching design and classroom teaching and teaching reflections.

People may wonder how to demonstrate a teacher's valuable sentiments of education of loving students. Loving students could not only be embodied from a teachers' serious teaching attitude but could be reflected from the content he has designed and arranged. 
For example, everyone saw eye to eye with each other including the judges and audiences that a teacher from a famous university in Hubei in 2018 demonstrated wonderful teaching from the perspective of her personal abilities. However, once we gave a second thought to one of the examples she offered, we realize this teacher hasn't noticed her responsibility as a teacher in influencing her students' outlook on life and world. The example she offered is "The Indian traffic police intercept the Indian president; The Chinese traffic police hold up common people." She used this example just as a kind of sharp contrast in writing a composition. However, she ignored the implication from the example she had chosen. Could all Chinese traffic be so unreasonable and ridiculous? Of course not! The information is absolutely misleading! But once a teacher says so, her students might believe her! Her students might become a cynic and pessimistic person as a result of her education and influence. Therefore, every teacher is supposed to be responsible for the development of his students. They are expected not only to teach their students useful knowledge but also to influence their students in a positive and optimistic way so as to make their students have a sunny attitude.

\subsubsection{Theoretical knowledge}

Exceptional contestants usually have a lot of different up-to-date educational theories, therefore, they focus a lot on creating a democratic and happy atmosphere, establish personal learning space and design cooperative teaching activities. For example, according to table 1, they know students can bear in mind $70 \%$ of what they have learned through communicating with others. Therefore, they may design group work in classroom teaching so as to better students' learning effect.

Table 1: The great majority's approaches to learning and effect

\begin{tabular}{|l|l|}
\hline Methods & Learning effect \\
\hline by reading & $10 \%$ \\
\hline by attending lectures & $20 \%$ \\
\hline by seeing in person & $30 \%$ \\
\hline by both seeing and listening to & $50 \%$ \\
\hline by communicating & $70 \%$ \\
\hline by applying and practicing & $80 \%$ \\
\hline by teaching others & $95 \%$ \\
\hline
\end{tabular}

(William Glasser, 1988)

WEN Qiu-fang's Production-oriented approach is a pedagogical innovation in university English teaching in China, which integrates second language acquisition theory into curriculum theory, upholds that practice is the sole test of truth, develops an approach to solve a specific problem with comprehensive strategies, and emphasizes the leading role of a teacher, and it has been widely accepted in China. ( WEN Qiufang, 2017:348 ) If a contestant has no idea about the new teaching approach, he is at least viewed as a poor learner.

What's more, they have grasped their own professional theoretical knowledge, and they can combine theoretical knowledge and practical knowledge well so as to prevent their students from grasping fragments information. As a result, not only can the students see the trees, but they can see the woods as well. In a word, the contestants are supposed to demonstrate that they possess systematical professional knowledge instead of fragments.

\subsection{Personal abilities}

An outstanding contestant is expected to be first rate in teaching skills, verbal and nonverbal communicative skills and phonological competence, 


\subsubsection{Teaching skills}

Teaching skills could be embodied in classroom lead-in, classroom questioning, error correction, blackboard designing, etc.

Could your teaching content always attract your students' attention? Are you good at questioning and stimulating your students to raise questions? How do you deal with your student's errors? What kind of role does the content on the blackboard play? To answer all these questions needs both rich knowledge and wisdom.

As the saying goes, "Well began is half done." Have you taken the students' interest and learning rules into your consideration when you design the lead-in? Is your lead-in interesting enough? Does your lead-in follow the principle of interestingness, learning-centeredness and pertinence? Could you make the best use of such different lead-in skills as reviewing old knowledge, introducing background information, telling the plot of a story, introducing the popular topics, using suspense, creating situations, using objects, using comprehensive methods, using songs or videos, etc? Meanwhile, the lead-in part can never occupy too much time; otherwise, the teaching may be top-heavy.

When you question your students, have you ever thought that students may have different learning capacity? Could your questions be thought-provoking or just make them feel fun? A plain-looking teacher left a deep impression on the judges and audiences in 2018 competition in that she could raise questions of different levels and from a different perspective so as to arouse her students' thinking. What's more, she also knew the skill of waiting 3-5 second before she put forward another question. Therefore, what she had done could put her students at ease instead of frightening her students with a storm of questions by offering her students some time to think about the question.

How do always deal with students errors? Do you just let the errors be so as to protect the students' dignity blindly or point out the errors skillfully? Of course, the latter is more reasonable. When encountering students' mistakes, teachers can choose to repeatedly speak out the right answer directly instead of pointing out the mistakes and correct them, or tell the students the mistakes after class, or teachers can ask other students to finish the same tasks, when they make the same mistakes, teachers can invite more students to correct them and finally teachers offer proper answers. Only under this circumstance, can students feel dignified and be ready to learn something new.

Blackboard-writing is not only a traditional teaching medium but also a tiny teaching plan. The content on the blackboard is supposed to be both striking and pleasing to the eye, which is expected to offer key points, so the trivial information should never be exposed on the blackboard, otherwise, it may distract students' attention. After all, we should bear in mind that LESS IS MORE. Besides, the arrangement of the key points also needs careful design, which is beneficial to both teacher's teaching and students' learning so as to better teaching effect.

\subsubsection{Verbal and nonverbal communicative skills}

As is known to all that both verbal and nonverbal communicative skills are essential to teachers. As for verbal communication, teachers are supposed to bear the following skills in mind:

\section{Using first-person pronouns}


First person pronouns could narrow the distance between teachers and students by making students feel that teachers are always on their side. In this case, students will be encouraged to follow the teachers' guide. For example, in order to cultivate students' ability to think critically, we can raise this kind of questions by using first-person pronoun: How can we defend the interests of both humans and animals? How to change our thinking mode by travelling? Under this circumstance, students may follow your guide naturally to answer the questions.

What's more, to some degree, using the first pronouns can avoid some misunderstanding. For example, when teachers want to check whether students have grasped what they explained, he'd better raise such question as "Am I understood?" instead of "Do you understand?", because the latter may convey that teachers underestimate students' ability.

\section{Using polysyllable adjectives and adverbs to make teaching infectious}

Polysyllable adjectives and adverbs are full of aesthetic feeling of the music, especially when teachers use three of them successively. For instance, in analyzing the character of the student in "Another School YearWhat For?"(YANG Li-min, 2012:2) written by John Ciardi, teachers can raise this kind of question "Don't you think the student in the first paragraph is arrogant, impolite and aggressive?" Infected by the tone and content of your speech, probably students in your classroom would like to seek the evidence to support your points of view. About the number of adjectives and adverbs, in China, we have the saying that things always go by three's. In a lot of English literary works, authors use at most three adjectives and adverbs to express their opinions incisively and vividly.

\section{Using polite expressions}

Polite expressions can make students feel they are respected and honoured, and then they are inspired to follow you. Therefore, when communicating with students, teachers had better use "Could you please do something...? Would you like to do something...? Please state your point of view..."

As for the function of nonverbal communicative skills, no teachers dare to ignore them. In teaching, good body language can embody teachers' personality cultivation, temperament and overall quality. Although body language is a silent language, it can also convey information and knowledge, infect students' moods, develop students' nonintellectual factors, influence students' quality, and intensify the effect of teaching. A psychologist believes the expressing of one's feeling is equal to $7 \%$ speech $+38 \%$ voice $+55 \%$ facial expressions, which just shows how important non verbal behavior is.

Take the champion LIU Wen-bo from Central China Normal University in 2018 teaching competition, for example, her body language was always impressive, infectious and unforgettable. She always spoke with a soft smile, a clear and dulcet voice, and appropriate gesture. Unlike other contestants, her movement was not confined to the platform; often she would move into the students and lower herself when she communicated with students. All these factors contributed to her success. In contrast, a lot of contestants paid little attention to these nonverbal communicative skills, and they just spoke fast to show their fluency without considering whether their students could follow them or not.

\subsubsection{Phonological competence}


Do you have a good command of word stress, sentence stress, pause, liaison, rhythm, and intonation? If you have no idea about phonetics or just have a poor understanding toward it, it's impossible for you to win out. Phonological competence is like a person's appearance. If you want the judges to love you, at first sight, you'd better bear standard pronunciation and perfect theoretical and practical phonological knowledge.

\section{The Power of Collaboration}

There is no denying that two heads are better than one, so the power of collaboration can never be underestimated. When faced with too many tasks, a contestant may feel at his wit's end. However, an excellent team may help you out by offering you a novel and up-to-date ideas, which could be embodied in designing teaching contents, bettering linguistic cohesion and semantic coherence, and preparing the questions to be raised by judges. Both LIU Wen-bo from Central China Normal University and LUO Wei from Yangtze University have powerful steering team made up of 6 members or so. And none of the contestants fights alone.

\subsection{Offering distinctive teaching designs}

Is your teaching design novel? Can your organization attract your students? Does your teaching have something to do with the current affairs?

Have you ever heard John Medina's theory “audiences check out after 10 minutes, but you can keep grabbing them back by telling narratives or creating events rich in emotion"? (John Medina, 2014:124) If you have, then you had better arrange different but related contents and teaching ways. However, to finish designing 20 sections is incredibly backbreaking and torturing. One contestant alone cannot complete such an enormous project. Take LUO Wei who won the second prize in 2018 teaching competition for example, in the initial stage, he had got five members' numerous help in designing each section. In the second stage, his design experienced countless modifications so as to make his design attractive and practical. According to him, he has benefited a lot from this teaching competition from different perspectives.

\subsection{Helping achieving linguistic cohesion and semantic coherence}

Some contestants have no idea about combining different parts together, so what they demonstrate are fragmentary organizations. Under this kind of circumstances, it is essential to offer some cohesive expressions so as to make a smooth transition. Take the following appreciation of "Unit 10 Pompeii" (YANG Li-min, 2012:240-243) for example: 
Table 2: Teaching procedures of Pompeii

\begin{tabular}{|c|c|c|}
\hline Tasks & Activities & Design Intents \\
\hline $\begin{array}{l}\text { Pre- } \\
\text { reading } \\
\text { tasks } \\
(3 \mathrm{mins})\end{array}$ & $\begin{array}{l}\text { Lead-in } \\
\text { 1. Let students list the most recent natural disasters that have taken } \\
\text { place in China. } \\
\text { Typhoon Dujuan leaves heavy damage in East China (Sept. 21, 2015) } \\
\text { The unforgettable earthquake in Yaan and Wenchuan } \\
\text { 2. Questions } \\
\text { Q1: What damage did they do to Chinese people? } \\
\text { Q2: What occurred in Pompei in AD } 79 \text { ? } \\
\text { 3. Information related to the text } \\
\text { Pompeii is an ancient Italian city on the Bay of Naples. Founded in } \\
\text { the 7th century BC, it became a prosperous city until completely buried } \\
\text { by the eruption of Mount Vesuvius in AD79. }\end{array}$ & $\begin{array}{l}\qquad \text { Students are } \\
\text { asked to talk about } \\
\text { natural disasters so as } \\
\text { to get close to the topic } \\
\text { of the volcanic } \\
\text { eruption of Pompeii. } \\
\text { Students are } \\
\text { asked to have a } \\
\text { general understanding } \\
\text { of Pompeii and draw a } \\
\text { map of Pompeii before } \\
\text { class. }\end{array}$ \\
\hline $\begin{array}{l}\text { While- } \\
\text { reading } \\
\text { tasks } \\
(14 \mathrm{mins} \\
\text { ) }\end{array}$ & $\begin{array}{l}\text { 1. Text analysis } \\
\text { 1) What is the main idea? } \\
\text { A brief introduction to Pompeii before and after August 24, AD } 79 \\
\rightarrow \text { A detailed description of what happened on the day of the eruption } \\
\text { Main idea: The volcanic eruption buried the prosperous and happy } \\
\text { Pompeii in AD } 79 \text { and about } 1700 \text { years later it was rediscovered. } \\
\text { 2) What was the city like before it was destroyed? } \\
\text { 3) What was the process of volcanic eruption? What was people's } \\
\text { reaction when the disaster started? Now, if you were trapped in a similar } \\
\text { disaster, what would you do? } \\
\text { 2. Theme analysis } \\
\text { A man should forever be humble and learn to respect natural laws } \\
\text { and learn whatever other useful lessons from them. } \\
\text { 3. Writing features and language expressions } \\
\text { 1) Writing features } \\
\text { a. Flashback } \\
\text { b. Imagination } \\
\text { the gladiators; the children; the town's important men; the wool } \\
\text { merchants; the bankers; the late-rising travellers from the East } \\
\text { 2) Language features(wide use of synonyms) } \\
\text { a. rush/dash/plunge into/fled/escape } \\
\text { b. tremble/collapse/topple/crash } \\
\text { c. ruin/damage/break/shatter } \\
\text { d. big/tremendous/giant/mighty/powerful } \\
\text { 3) Figures of speech } \\
\text { simile/metaphor/personification/parallel /euphemism } \\
\text { 4. Critical thinking } \\
\text { Read the author's description of the volcanic eruption and then } \\
\text { discuss the question: } \\
\text { What can we do faced with disasters? }\end{array}$ & $\begin{array}{l}\text { Students are asked } \\
\text { to retell the story by } \\
\text { analyzing the writing } \\
\text { clue of the text so as to } \\
\text { get the main idea } \\
\text { smoothly, and they are } \\
\text { expected to answer the } \\
\text { questions so as to get } \\
\text { the theme. }\end{array}$ \\
\hline $\begin{array}{l}\text { Post- } \\
\text { reading } \\
\text { tasks } \\
(3 \mathrm{mins})\end{array}$ & $\begin{array}{l}\text { 1. Summary } \\
\text { 2. Assignments } \\
\text { 1) Explore more information online about the volcanic eruption that } \\
\text { destroyed Pompeii in AD } 79 \text { and reports your findings to the class. } \\
\text { (http://www.tudou.com/programs/view/gQHkXXOQukE/) } \\
\text { 2) Watch the powerful movie called The Last Days of Pompeii } \\
\text { after class. }\end{array}$ & $\begin{array}{l}\text { A summary can help } \\
\text { students organize the } \\
\text { knowledge they have } \\
\text { accumulated. } \\
\text { Assignments can } \\
\text { improve students' } \\
\text { writing ability and } \\
\text { broaden their horizons. }\end{array}$ \\
\hline
\end{tabular}


According to the above teaching procedures, the 20-minute teaching content is made up of 3 parts, and each part consists of many mini parts. Especially the second part--while-reading tasks-is composed of 5 mini parts. By no means can we casually say that let's move to the next part after finishing the previous part. Instead, we should pay more attention to the inner connections between each part.

For instance, after we've already known the main idea of the text, and intend to move to the analysis of the theme of the text, it is necessary to mention that "Class, we may wonder why the author wrote this article. Was he going to describe the horrible scene so as to make us feel horrified? If not, let's analyze the theme of this article and get to know the author's real purpose."

Before we move to the writing features, we also need to say something to make our transition as smooth as possible. Under this circumstance, we can say that "Undoubtedly, this article is well written. Class, could you tell me how the author achieved this standard? That is to say, what kind of writing skills did the author use?"

The list is endless. In a word, before we move to the next part, we need to give it a second thought so as to make the transition as natural as possible.

\subsection{Presupposition of judges' questions and answers}

Just as what the ancient Chinese philosophical book The Art of War concludes if you know yourself and your enemy, you'll never lose a battle. Therefore, to predict what kind of questions the judges may raise is very conducive to the contestants.

\section{Conclusion}

In order to make ourselves more competitive, not only should we try to better ourselves in personal qualities and theoretical knowledge, personal abilities, teaching skills and strengthen the cooperation with our colleagues, but also it necessary for us to take the following advice: (i) Keep challenging ourselves by trying our utmost to offer new courses, and bear it in mind that everyone has great potential. (ii) Lower ourselves so as to learn from others. A lot of people are like a storehouse of knowledge and wisdom. However, no one would like to share anything with arrogant people, so it is necessary for us to "stay hungry and stay foolish" so as to enrich our knowledge. (iii)Improve theoretical knowledge by reading, reflecting and communicating a lot.

\section{References:}

[1]. William Glasser, Association for Supervision \& Curriculum Development Guide, 1988

[2]. WEN Qiufang, Chinese features displayed in the production-oriented approach [J], Modern Foreign Languages (Bimonthly), 2017: 348.

[3]. John Medina, Brain Rules[M], Pear Press, 2014: 124

[4]. YANG Li-min, Contemporary College English, Beijing: Foreign Language Teaching and Research Press, 2012:2-5; 240-243. 